This is an electronic reprint of the original article. This reprint may differ from the original in pagination and typographic detail.

Author(s): Kontinen, Tanja

Title: Biohit: A Global, Family-Owned Company Embarking on a New Phase

Year: $\quad 2014$

Version:

Please cite the original version:

Kontinen, T. (2014). Biohit: A Global, Family-Owned Company Embarking on a New Phase. Entrepreneurship Theory and Practice, 38(1), 185-203.

https://doi.org/10.1111/j.1540-6520.2011.00488.x

All material supplied via JYX is protected by copyright and other intellectual property rights, and duplication or sale of all or part of any of the repository collections is not permitted, except that material may be duplicated by you for your research use or educational purposes in electronic or print form. You must obtain permission for any other use. Electronic or print copies may not be offered, whether for sale or otherwise to anyone who is not an authorised user. 


\title{
Biohit: a global, family-owned company embarking on a new phase
}

Kontinen, T. Biohit: a global, family-owned company embarking on a new phase. Entrepreneurship Theory and Practice, in press.

\begin{abstract}
This case concerns Biohit, a family-owned biotechnology company established in Finland in 1988, selling liquid handling and diagnostics products in the global market. The case also describes the entrepreneurial career of Biohit's CEO Osmo Suovaniemi, since the company is mainly based on the know-how that Osmo gained as ownermanager of his two earlier companies, Labsystems and Eflab, during the 1970s and 1980s. Hence, this case describes the prior and initial phases of Biohit, examining also its commitment to innovation and its management practices. The case ends with the situation as of March 2010, and includes the reflections of Biohit's managers on the future of the company. At this point, Osmo was intending to hand over his executive position to someone from outside the family, on the grounds that none of his three sons was able or willing to take up the position. However, he planned to continue as owner, inventor, and full-time board member of Biohit. The managers of Biohit had high hopes of making a breakthrough with diagnostics products that had been under intensive development over a long period.
\end{abstract}

\section{INTRODUCTION}

On April $1^{\text {st }} 1988$, Osmo Suovaniemi ${ }^{i}$ decided to launch a company called Biohit. His career as an entrepreneur had begun in the 1970s with two successful firms that he himself had founded: Labsystems Ltd (established 1972) and a joint venture Eflab Ltd (established 1978). However, in 1986, Osmo was forced to sell these two companies to Skopbank. He claimed that Skopbank had acted illegally, and bitter legal disputes followed. Feeling that he could no longer carry on, he left the companies and started up a new venture, Biohit, which is now one of the most successful companies in its field. The Suovaniemi family has a strong presence in Biohit, since in addition to the whole company being currently centered on Osmo, family members have an ownership share of about $70 \%$ in the company, which is publicly listed. Furthermore, the Suovaniemi family controls an even larger proportion of the decision-making power, since they have share capital entitling them to $88 \%$ of the voting rights (for more information on the ownership of Biohit, see Exhibit 1). In March 2010, Biohit was on the point of entering a new phase, since Osmo wanted withdraw from his central role in the firm, handing over his executive position to an employee who was not a member the family. 
The stated mission of Biohit is to improve people's quality of life and well-being, as summed up in the phrase "Innovating for Health." Biohit develops, manufactures, and markets liquid handling products, diagnostic tests, and analysis systems. Biohit is the global market leader in electronic pipettes, and its range of electronic and mechanical liquid handling devices is currently the widest in the world. Sales abroad make up $96 \%$ of the company's total sales. Biohit's products are sold in 70 countries by approximately 450 distributors. The products of Biohit involve a high degree of processing, and have a domestic content of approximately $95 \%$. The headquarters of the company are in Helsinki, Finland, with production plants situated in Finland and in China. Biohit has subsidiaries in France, Germany, the UK, Russia, China, India, Japan, and the USA. There is also a representative office in Singapore. Currently, the Biohit group has approximately 370 employees spread over eleven countries. The company's B shares have been quoted on the NASDAQ OMX Helsinki, Healthcare since 1999. The key customers of the company are health care organizations and services, research institutions, industrial laboratories, and general practices. Consumers constitute a new customer group for Biohit, since the company has developed new tests for various ailments, including stomach illnesses. Important customers include Eastman Kodak Co. Clinical Diagnostic Systems (later acquired by Johnson \& Johnson), Becton Dickinson, and $3 \mathrm{M}$.

Biohit has an aggressive innovation and patenting strategy, developed by Osmo himself. Osmo has about 70 patents in Finland. Indeed, he could be said to have set an example for companies of all sizes in Finland, in terms of innovating and patenting. In the Finnish media (Biohit, 2002: p. 1), it has been claimed that in two of Finland's largest companies, Nokia and KONE, the patenting strategy was adopted at least in part from Osmo's companies. This might be partly connected to the fact that an employee who had been responsible for patenting moved from one of Osmo's companies to KONE, and later to Nokia phones, during the 1980s.

Exhibit 1. Ownership of Biohit. 


\begin{tabular}{|c|c|c|c|c|c|c|}
\hline Shareholder & $\begin{array}{l}\text { Number of A } \\
\text { shares }\end{array}$ & $\begin{array}{l}\text { Number of B } \\
\text { shares }\end{array}$ & $\begin{array}{l}\text { Number of } \\
\text { shares }\end{array}$ & $\begin{array}{l}\% \text { of } \\
\text { shares }\end{array}$ & Votes & $\begin{array}{l}\% \text { of } \\
\text { votes }\end{array}$ \\
\hline $\begin{array}{l}\text { Suovaniemi } \\
\text { Osmo Antero }\end{array}$ & $2,265,340$ & 965,207 & $3,230,547$ & 24.97 & $46,272,007$ & 66.61 \\
\hline Biocosmos Ltd. & & $1,142,735$ & $1,142,735$ & 8.83 & $1,142,735$ & 1.64 \\
\hline Interlab Ltd. & & $1,021,762$ & $1,021,762$ & 7.9 & $1,021,762$ & 1.47 \\
\hline $\begin{array}{l}\text { Suovaniemi } \\
\text { Ville Roi }\end{array}$ & 208,280 & 371,300 & 579,580 & 4.48 & $4,536,900$ & 6.53 \\
\hline $\begin{array}{l}\text { Joel } \\
\text { Suovaniemi }\end{array}$ & 208,280 & 333,000 & 541,280 & 4.18 & $4,498,600$ & 6.48 \\
\hline $\begin{array}{l}\text { Suovaniemi } \\
\text { Oili }\end{array}$ & 111,600 & 288,935 & 400,535 & 3.1 & $2,520,935$ & 3.63 \\
\hline $\begin{array}{l}\text { Etera Mutual P } \\
\text { Insurance Com }\end{array}$ & $\begin{array}{l}\text { ension } \\
\text { jany }\end{array}$ & 363,138 & 363,138 & 2.81 & 363,138 & 0.52 \\
\hline Etra Invest Ab & & 333,000 & 333,000 & 2.57 & 333,000 & 0.48 \\
\hline $\begin{array}{l}\text { Härkönen } \\
\text { Matti }\end{array}$ & 57,200 & 269,515 & 326,715 & 2.53 & $1,413,515$ & 2.03 \\
\hline $\begin{array}{l}\text { Suovaniemi } \\
\text { Vesa Jukka } \\
\text { Markku }\end{array}$ & 74,800 & 194,499 & 269,299 & 2.08 & $1,690,499$ & 2.43 \\
\hline
\end{tabular}

\section{OSMO SUOVANIEMI}

Osmo Suovaniemi ii, Doctor of Medicine, PhD, Professor, was born in 1943 in Kihniö, Finland. He was the second son of a farming couple. In addition to farming, Osmo's parents ran a sawmill. At high school, Osmo met his future wife, Oili, who was the daughter of another farmer in Kihniö. Osmo moved to Helsinki for his studies in medicine and Oili studied nursing in Jyväskylä. They got married in 1964 and their first son, Vesa, was born the same year. Their second son, Ville, was born in 1978 and their third, Joel, in 1981. There is a considerable age difference, fourteen years, between the first and the second son. Between the birth of the first and the second son, Osmo and Oili concentrated on launching their first enterprise, Labsystems.

\section{First steps in the entrepreneurial career of Osmo Suovaniemi}

Osmo's background was far from wealthy. While he was studying medicine in the 1960s he found he had an interest in research, becoming involved in doing what he later called "special work" at the university, in a research capacity. Since he did extremely well in the branch called medical chemistry, he was later given a post as an Assistant. Osmo describes this phase of his life as follows:

"As well as being a student I did what you could call "special work" and worked as an Assistant. And at the weekends, I did emergency duties and worked as a doctor in psychiatric outpatient care. So I did lots of things. That was a very creative and active time. Well, as we know, people are at their most creative around the age of 20." 
While doing his special research, mostly at night, Osmo learned how to use pipettes and microscopes. He found that the equipment was awkward to use. When he was doing his experiments, he almost swallowed a piece of rat's brain, and sometimes the rats bit him. It also took a lot of time to do all the experiments.

"That is how I ended up developing the pipettes. I developed the first single-and multichannel adjustable mechanical pipettes in the world. It was actually hard to get enough glass pipettes from our manufacturer to develop the multichannel pipettes. You needed to ask in a very humble manner just to get one glass instrument, so nine pipettes was an awful lot to ask. Aside from this, I also created an analyzer, because after I had dozed off for a while I needed to measure the liquid somewhere."

This was at the end of the 1960s. As his experiments began to go more smoothly thanks to his innovations, he was motivated to develop them further. At the start of the 1970s, when Osmo was just about to graduate as a doctor, he offered his inventions - which he had developed in the kitchen of his small apartment - to Finnish industry, approaching companies such as Valmet, Huhtamäki, and Instrumentarium. At this point he wanted to get some money for his innovations and to start working as a medical doctor. However, the companies he approached did not really understand the logic of his products. Since they were not prepared to give him even the amount of money he had spent on developing his innovations, he ended up going into business himself. Initially, he was involved in some small-scale business, concentrating on product development (Osmo A. Suovaniemi Ltd; Finpipette Ltd.). As Oili sees it, they really got into running a business in 1970. This was when Osmo had the pipette molds made - and when he gave Oili an instruction manual on bookkeeping. Yet in Oili's opinion they never actually made a decision to launch a firm; it was more a situation that they found themselves slipping into. Osmo describes the decision to set up a business as follows:

"It was a really tough decision to study for six-and-a-half years and graduate as a doctor and then set up a firm. My relatives were putting on the pressure, they kept saying how bad it was for Osmo that he did not become a communal doctor, that he became an entrepreneur, someone who made things. It really meant that I took a path of my own. But I have not regretted it for a moment. It has shown me that being an inventor and entrepreneur is as essential for me as stripes are for zebras."

Osmo also wanted to learn about business; thus he studied at Helsinki School of Economics and Business Administration in 1976-1977. Oili describes their entrepreneurial life as follows:

"I have always loved routines and Osmo has loved innovating, so it has been natural to take these roles in the enterprises, too. We have always worked long hours, but of course I was at home for many years, when our sons were small. But there, too, I helped by looking after the 
guests of our firms when they came to the house, and by listening to Osmo. Of course, I might have affected some decisions through the kitchen door as well. Thinking of our free time, when we had small children we took more time off then, going to the sea or to our summer cottage in the evenings and at weekends, but even there I often realized that Osmo's thoughts were on the business. It has been so important for him. And it has been an interesting life for me, as well."

Oili says that she has always supported her husband's decisions, and has trusted them. Oili has worked as Chief Cashier of Osmo's firms throughout, except for the beginning of the 1980s when she had two small sons to look after. Even at this point she took care of guests: she served meals and discussed business matters with Osmo whenever they were on his mind. Oili is of the opinion that as a couple they took risks, but asks where else they would have invested their money. For his part, Osmo sees challenges and risks as having been very important to him:

"Well, I can say that I have taken huge risks. But I have never really thought of the risks. I would say that the more troubles or challenges I have, the harder I work. But if something is too easy, I very easily get lazy. I'm extremely lazy by nature. That's also why I created multichannel pipettes at the end of the 1960s - it was so frustrating to measure with just one channel. I created a pipette with nine channels."

Innovations and product development have always been close to Osmo's heart. He has been awarded some seventy patents in Finland alone and several hundred worldwide, mainly in the fields of medical laboratory diagnostics, optics, and mechanics. In 1994 Osmo was awarded a PhD from the University of Helsinki, and in June 2002 the President of Finland awarded Osmo the title of Professor.

\section{PRODUCTS}

\section{Liquid handling}

As mentioned above, Biohit has two major business segments: liquid handling and diagnostics. The management groups for the different products are shown in Exhibit 6 in the end of the case. Liquid handling products (see Exhibits 2 and 3) include electronic and mechanical pipettes, disposable tips, and pipette maintenance and calibration for the customers buying these products. The primary customers are the laboratories of hospitals and research institutions. Liquid handling products - pipettes and tips - are basic laboratory tools. According to the company's own estimate, the average annual growth in the total market for pipettes has been 5\%. Market growth has slackened off in recent years due to the global recession. Growth has mainly occurred in electronic 
pipettes (about $10 \%$ annually) and disposable tips (about $20 \%$ annually). The largest market areas are North America and Europe, but the importance of Asia is also increasing. More efficient $R \& D$ and production processes are leading to increased automation in certain segments. A notable feature is that in industry there is a move away from handheld pipettes towards computer-controlled analysis systems, and towards liquid handling equipment using robotics.

Exhibit 2. Electronic pipette eLine by Biohit.

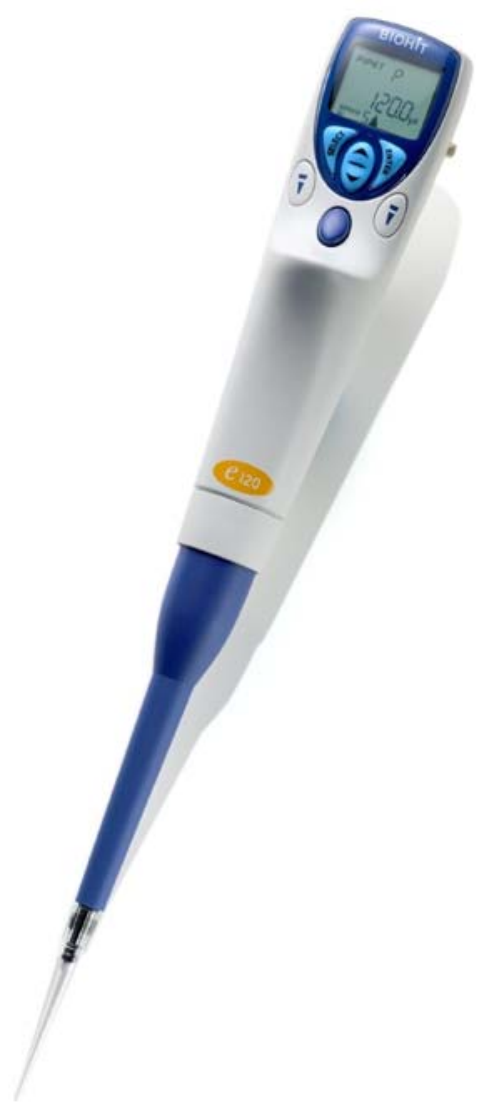

The operators in the liquid handling market include several larger global manufacturers and marketers, plus numerous smaller players. Increases in supply together with cheap production have intensified price competition. However, strict quality and safety standards have made market entry difficult for copycat products, most of which are manufactured in Asia. Biohit has invested substantially in quality in all its production facilities and operations. The company is still the global market leader in electronic pipettes and OEM (Original Equipment Manufacturer) liquid handling products, and is a pioneer in terms of promoting high quality and the safe use of its products. Rapid delivery of disposable products to customers has become a major competitive factor, and thus Biohit has put a heavy emphasis on improving the efficiency of its distribution processes throughout the Group. 
As the level of precision and safety demanded in liquid handling rises, and as quality assurance regulations become stricter, equipment performance and measurement traceability have become a challenge for many laboratories. Pipette accuracy must be ensured via calibration and performance testing that complies with quality standards. The provision of accredited calibration services has given Biohit a competitive edge.

\section{Exhibit 3. Service lab by Biohit.}

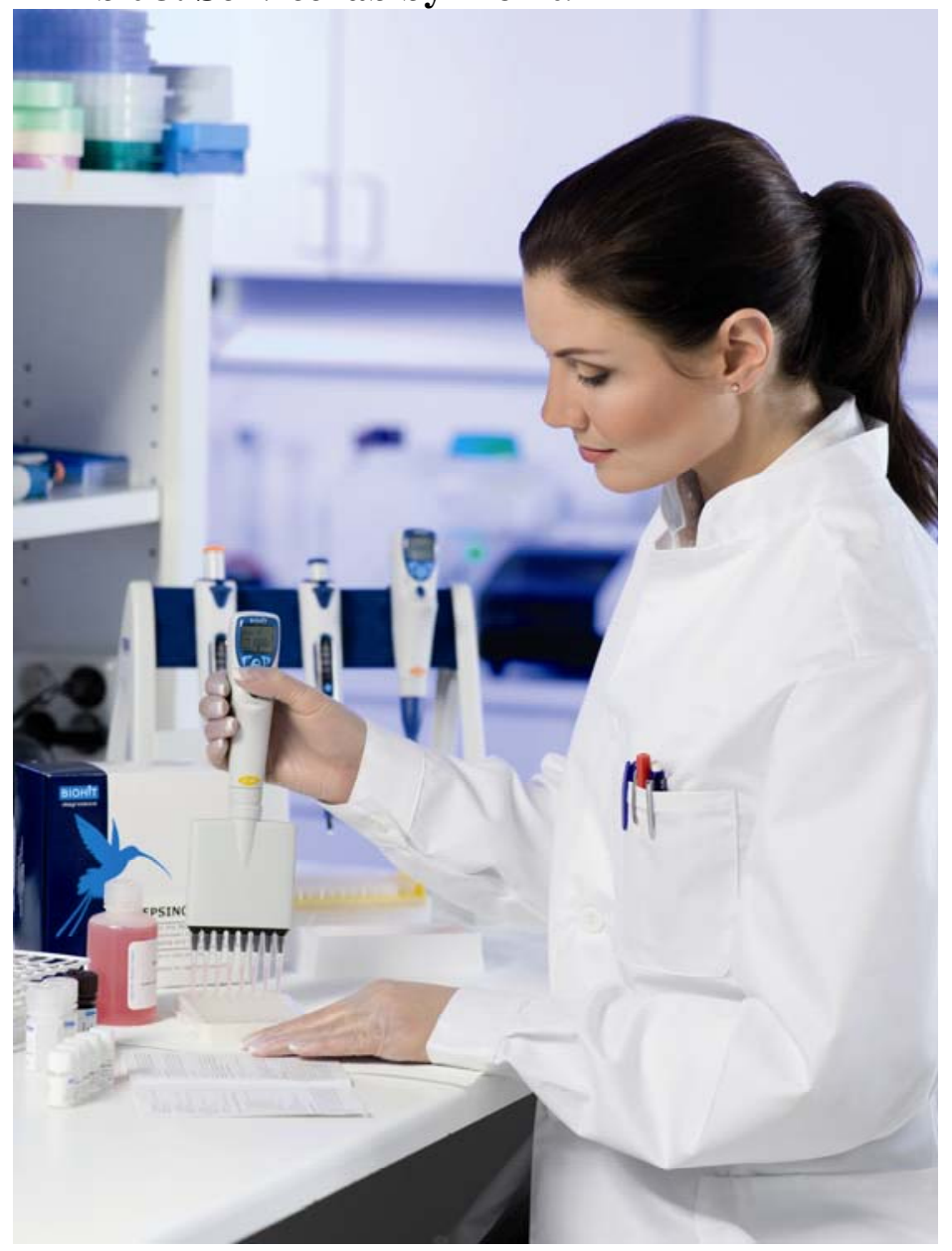

\section{Diagnostics}

The diagnostics segment (see Exhibit 4) consists of products and analysis systems for the early diagnosis of gastrointestinal diseases. Biohit equipment permits blood-sample based GastroPanel examinations for the diagnosis of stomach illnesses and associated risks, quick tests for the diagnosis of lactose intolerance and Helicobacter pylori infection in connection with gastroscopy, and the ColonView examination for the early detection of fecal occult intestinal bleeding (faecal occult blood), which would indicate a risk of colorectal cancer. Its Acetium innovation was developed to reduce carcinogenic acetaldehyde in the gastrointestinal tract. Overall, the key objective of the diagnostics 
business is to prevent diseases of the gastrointestinal tract. The primary customers are health care practitioners and a number of health care chains, such as Terveystalo in Finland.

Exhibit 4. Gastro Panel Diagnostics by Biohit.

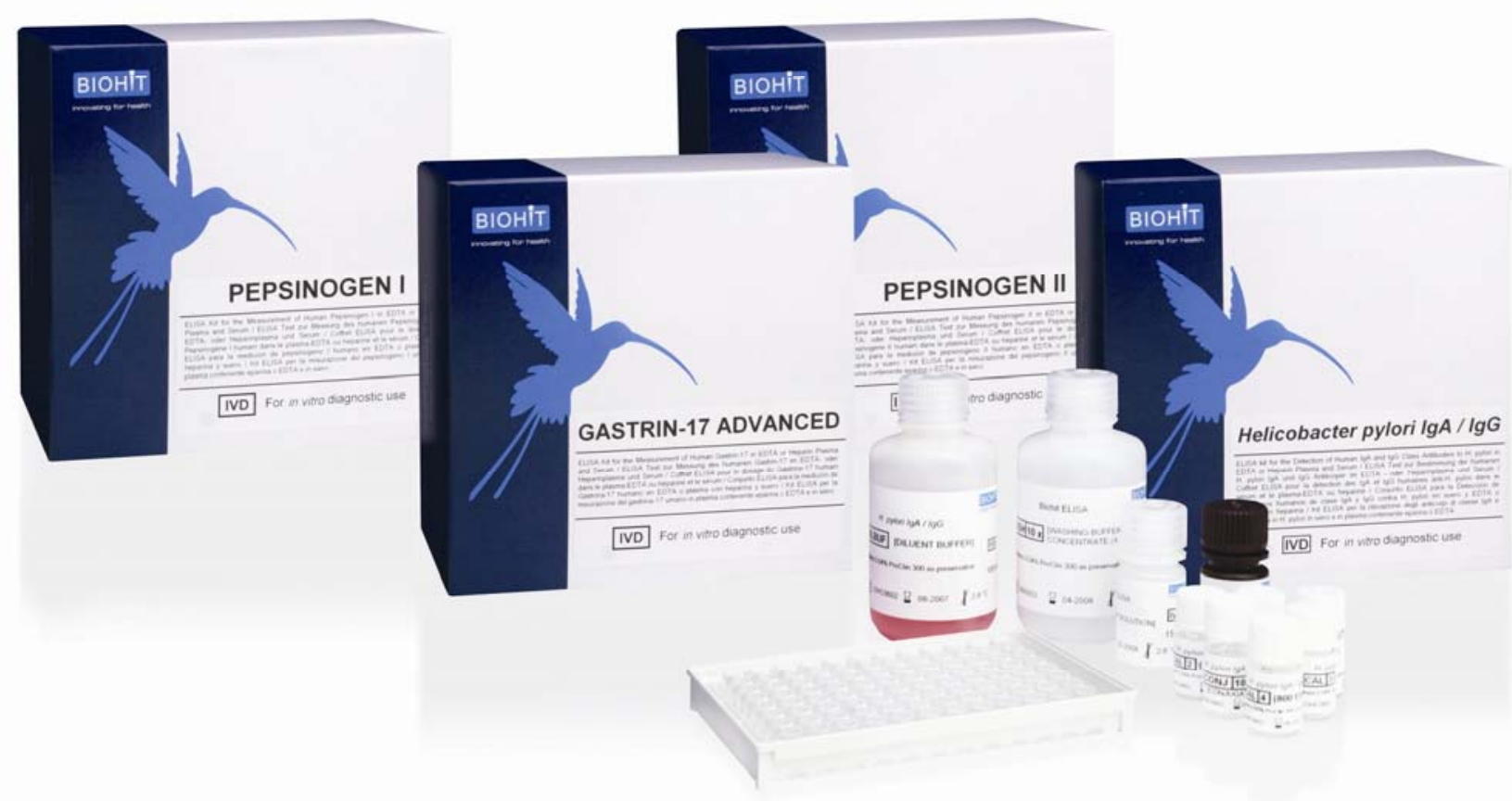

In addition to large global companies, the companies in the diagnostics market include smaller companies such as Biohit, which specialize in particular diagnostic fields. Harnessing the huge market potential of Biohit's diagnostic products requires proactive sales and marketing, and also cooperation with strong partners who specialize in diagnostics.

\section{LAUNCHING A BUSINESS: The foundations of Biohit}


As mentioned above, Biohit had two precursors: Labsystems and Eflab. It is important to understand the developments in these companies in order to understand the story of Biohit. The chronology of events in these companies will thus be outlined in the following paragraphs.

Since Osmo found that no company was interested in his innovations in the late 1960s/early 1970s, he established Labsystems in 1972. Osmo was the inventor, and Oili took care of the book-keeping. Being an entrepreneur meant working in their small apartment, doing experiments and development work in the kitchen and bathroom. As time passed, Osmo hired new people to work for the firm, and Labsystems started to grow. Huhtamäki Ltd. took care of the export of pipettes until 1977, when Osmo ended the contract. Huhtamäki had operated illegally, and Osmo won the ensuing court case. After terminating the contract, Osmo hired a new person for international marketing and sales. At the same time, product development continued. Aside from pipettes and analyzers, the company developed diagnostics equipment. Together, the products formed an analyzing system which allowed different kinds of diagnoses, and which could be used by researchers and other laboratory personnel.

\section{A time of growth}

Aside from running Labsystems, in 1978 Osmo established an international joint venture, Eflab, with American partners. Eflab started to sell multichannel pipettes and microplate analyzers around the world. The venture was a huge success. Both of Osmo's firms grew, to such an extent that they were now the fastest growing companies in the industry. It appeared that these firms were responding to what clients really needed. For instance, Labsystems was the first firm to launch AIDS tests at the start of the 1980s. Osmo felt that as a doctor, he was to some degree a customer for himself. From this starting point he came up with dozens of new inventions.

These innovations, developed at the end of the 1970s, are still in use around the world. However, other pipette firms started to copy the single and multichannel pipettes made by Labsystems as soon as the patents expired (it is worth noting here that the pipette business is worth around 2 billion Euros annually at the present time). Later, the microplate analyzers, too, were copied (current analyzer business amounts to 2-4 million Euros annually). In 1984 Labsystems became a publicly listed company, with the number of its patents exceeding any of the large Finnish firms such as KONE Ltd. or Nokia Ltd.. Nonetheless, patenting skills moved from Labsystems to Nokia when Timo Louhi, who had implemented an aggressive innovation and patenting strategy in Labsystems, moved to KONE and later to Nokia phones.

In the mid-1980s, there was also an episode when Pekka Herlin from KONE wanted to buy out Osmo's companies. Osmo did not wish to sell them and Herlin took him to court. He claimed that Osmo's companies had libeled KONE. The legal proceedings went on for eight years, and Herlin lost all of them. However, before the 
end of these proceedings, there was a serious setback that led to Osmo leaving his two successful companies.

\section{A serious setback}

In the spring of 1986, the Finnish bank, Skopbank, made Osmo an offer of collaboration. Since Osmo was innovating extremely rapidly, extra money was needed, and he signed the contract of collaboration in May 1986. However, this collaboration turned out to have dire consequences. According to Osmo, Skopbank had no intention of fulfilling the agreement. Instead, Skopbank planned to create a sizable cluster of companies in Finland, using Labsystem's ideas as the core. At that point, Osmo had no idea what was envisaged.

"One of Skopbank's managers was my neighbor and he kept telling me how they wanted to finance my companies and create a new enterprise dynasty. I had been taught to trust the banks and I thought that banking people were honest, so I agreed. That was a terrible mistake, a true catastrophe! After forcing me the sell my shares, they immediately made a profit of 200 million marks. I became furious when I realized that they just wanted to take advantage of me, but they blackmailed me, telling me that if I did not sell them the majority of the shares of Labsystems,

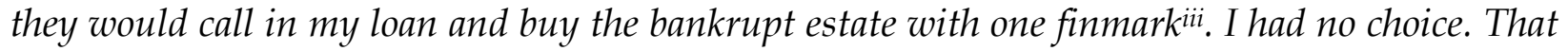
was how they got control over the company."

Osmo took Skopbank to court. In Skopbank, notes were found showing secret calculations as to how they would break the agreement, make "enormous profits" and "raise Skopbank's image." The indictment against Skopbank was "pre-planned grand blackmail," but the charges were rejected, since there was not sufficient evidence to show a crime had been committed. As a consequence, Eflab too ended up under Skopbank's control, and Osmo left both companies.

"With this Skopbank tragedy, I became a victim of the Finnish casino economy that imitated the criminal traits of the US savings-and-loan crisis at the start of the 1980s. My extensive work was destroyed and what little remained after the collapse of Skopbank in 1991 was sold to foreign owners in 1993."

\section{A new venture: the creation of Biohit}

"Of course, I left Labsystems and Eflab (in 1986), and wondered for a while what to do. But then in 1988 I established Biohit. Undeterred by my experiences, I decided to continue my work as an inventor and entrepreneur. 'What does not kill, makes you stronger' is true in my case. It took pioneering spirit, new innovations, and entrepreneurialism to establish Biohit in 1988. For my part, I can only say that once an inventor and entrepreneur, always an inventor and entrepreneur."

According to Oili, Osmo never slid into depression, and was always looking for new opportunities. He was offered a good job, but he refused, because he could not see 
himself as an employee. Now the Suovaniemi family once again put all their money into a new venture, tying up their capital for the first two years. "What else would we use our money for, there is no better choice that a business enterprise," said Oili. In addition to their own capital, Biohit received some funding from TEKES (the National Technology Agency of Finland) during the initial two-year product development phase. When Osmo launched Biohit, he gathered a good team around him, taking on the best employees from Labsystems. Their first thought was "What would we do?" followed by "What can we do?" and "What would give us some competitive advantage?" Almost everybody from Labsystems would have liked to join Osmo's new company, but he was not able to take everyone, simply to "skim the cream." All of these employees still work for Biohit. Erkki Vesanen, also from Labsystems, joined the company in the autumn of 1989, the eleventh person to do so. He explained that his arrival was a kind of a milestone, since at that point the staff of Biohit could no longer fit into the Suovaniemi kitchen: the women, including Oili (who cooked for the staff in addition to planning the business together with her husband), started to eat in the dining room, while the men remained in the kitchen. A year-by-year history of Biohit is presented in Exhibit 7 in the end of the article.

During its early years, Biohit successfully developed and commercialized two more of the inventions that Osmo had come up with in the 1970siv. Erkki described this as follows:

"We started to develop a new generation of pipettes, products that the world had never seen before. We studied the technology available around the world, and also did a lot of basic research. We then saw that 'utopian' technologies were not the best alternative, and ended up creating an electronic pipette that did not exist anywhere in the world. Of course it was a big risk to have people with high salaries sitting in the cellar for two years, and the only thing we had was belief in the product."

However, the electronic pipette faced many problems in the market - it did not work well enough initially, and not all customers were ready to exchange their mechanical pipettes for electronic ones right away. Since Biohit needed some cash flow, the company rapidly developed a mechanical pipette, and succeeded in selling it. At the same time, they also managed to get the electronic pipette to work to its full potential. The mechanical pipettes were planned with a disposable tip. Hence, at the end of the 1980s, there arose a need to produce tips for the mechanical pipettes. A factory was established Kajaani, Eastern Finland, in 1990, and the number of employees increased. Product Development Manager Vesanen describes this phase as follows:

"Disposable tips offer a self-growing business: once you sell and deliver them at a reasonable price as agreed, new orders come in every now and then, and the sales grow by themselves."

As Vesanen sees it, Biohit was launched at a good time, since its three biggest rivals, Wilson, Eppendorf, and Labsystems were well-established companies, and there were 
good opportunities to attack with clearly-differentiated products. Biohit made things in innovative ways. Since product development was so expensive, the staff of Biohit had to be creative in sales and marketing. For instance, they agreed to customers putting their own labels on the products, and they provided customers with a smaller, but more individualized range of products. Vesanen explains their flexible strategy as follows:

"The second largest pipette house in the world started selling our electronic pipette. We said that it was a better alternative than if they developed one of their own. We didn't realize it at that point, but it was a great strategy: we got them to concentrate on something else for five years and we had the chance to develop our electronic pipette further."

Several customers wanted to see their own company's name at the top of the pipette and Biohit had no problem with this, since the company got the sales it needed. As a second strategy, Biohit replaced existing analyzing systems with tailor-made electronic pipetting systems: customers were given precisely the application they needed. The strategy was highly customer-oriented.

\section{Expansion of Biohit}

After developing several successful and innovative products, Biohit embarked on international expansion. Osmo had such strong personal networks from his previous businesses that the establishment of the first foreign subsidiaries happened almost by itself, via previous friends and business partners from abroad. As an example, Regis Carnis set up a French subsidiary in 1991. Osmo describes this as follows:

"We were good friends, I and Regis Carnis. It was very natural that we would start cooperation after I launched my new firm. He wanted to work for me and not for my previous firms, which had been taken over, so he resigned right away when he heard about my new firm. [...] Over all these years, I have got to know him extremely well. We can trust each other $100 \%$, we have respect for each other's opinions, have similar kinds of values in life and are interested in similar kinds of things."

Regis explains his decision to start a subsidiary for Biohit in the following manner:

"They offered me a five-year agreement [in Labsystems] and they offered to double my salary. I said "No, I'm leaving. I have decided I'm leaving." In Biohit, I like it that you have a certain way of doing business, meaning that there is business but there is private life as well, and nature and so on. And that is the main reason why I am still working with him. What makes our relationship unique is the respect we have for each other and the inspiration our field gives us. We seem to see the world in the same way, we share values. He is a true entrepreneur. He doesn't think about money so much, all the other aspects come first. And he also gives total freedom to me. I feel really comfortable with being able to run the French subsidiary in my own way. He always trusts me: if I want to do something, he says, yes, do that, you know what is best for you there." 
In 1992, Biohit established subsidiaries in Great Britain and Italy. In these countries, too, Osmo was able to use his existing network ties from previous companies. His truly entrepreneurial philosophy of business made previous partners want to join Biohit, even if they had to start from scratch. The Japanese joint venture was established in 1994, but without previous network ties there - hence a new partner had to be found. Japan has been a difficult market, and altogether there have been four changes in the manager. The German subsidiary was established in 1995. Since then, Biohit has established subsidiaries in the USA (2000), Russia (2000), China (2003; a production subsidiary in 2006), and India (2009). Biohit went public in 1999. In 2005, Biohit had 295 employees worldwide, and in 2009 the number had increased to 370.

\section{INNOVATIONS AND PRODUCT DEVELOPMENT}

Biohit and its precursors have been characterized by customer-oriented product development and new inventions, plus a willingness to be different, to move ahead of their competitors, and to seek to improve the health of people around the world. The first two years of Biohit were spent on product development, with large sums of money being used to develop the first electronic pipette in the world. There was considerable risk as well, but the team did not give so much thought to the risk, believing as they did in their work and inventions. In addition to its innovations, Biohit's competitive advantage was based on the firm's deep knowledge of the products of the industry, an ability to react quickly to customer needs, knowledge of distribution channels, Osmo's reputation, and Osmo's excellent network ties around the world. Indeed, almost all his previous partners and employees from his previous companies wanted to work for him when he launched Biohit.

Product development in Biohit is an ongoing activity: all profits have been spent on it and on the creation of new jobs and exports. As mentioned above, the first innovations were electronic pipette and testing systems, mechanical, personalized pipettes, and disposable tips. These innovations were followed by diagnostic systems. Product development has also been based on doctoral dissertations, the first of these being written in 1992, followed in 1994 by the thesis written by Osmo himself. In 1996, a thesis on diagnostic systems was completed, and this was clearly an important element in the diagnostic systems development of Biohit. Biohit also has university-level research partners in China, the USA, Russia, and Japan. For instance, in the innovation called GastroPanel, international cooperation plays a large part. As regards patenting, rivals have copied Biohit's products, legally once the patents have expired, but also illegally:

"Of course all of my innovations have been copied, because they have been such good products. We do not need to imitate anyone. They imitate us, but often they do it very well. It irritates me sometimes that they do it so well, before we have had time to take advantage of our innovations. 
However, in recent years we have avoided large-scale patenting, since it is extremely expensive. It's only when we invent something significant that we apply for a patent."

Product development does not always mean high technology, as Vesanen, the Product Development Manager, explains:

"Innovation often means simplification. Many products have been over-engineered, and competitors over-engineer them even more by creating five more features than their rivals. Creating a breakthrough product sometimes means that you only use $20 \%$ of the existing features. This is similar to the iPod strategy. In the end, people like quite simple things, so long as they have all the necessary features. We have had to think radically, because our competitors follow us."

Since competitors tend to follow the lead of Biohit, Osmo does not regard (for instance) his ex-company, Labsystems, as a true competitor:

"No, Labsystems is not our competitor. They don't do things so well, they cannot beat us. Of course, they are doing well in the sense that they are making a lot of money. It is thanks to my old inventions that sell so well! But I am satisfied. I am happy for others who have taken advantage of my inventions. But anyway, if the big companies want to complete their diagnostic systems, they always come to us. And overall, it's good to have competitors, after all, we can't take on the whole world."

Currently, Osmo is involved in a product development project with two old friends:

"We call it the 'retirement project,' although I'm not retired yet. We are working on a vertical analyzer. And quite deliberately, we are doing it in such a way that it will be so profitable and multipurpose that it will take markets away from all the others. We expect it to be finished by the end of this year [2010]."

In the diagnostics of stomach illnesses, Osmo and his colleagues identified a huge unmet need in the 20th century. The diagnostics were poor, and Biohit developed better, easier systems, such as GastroPanel. However, doctors are slow to adapt to new innovations, and for this reason, the sales in diagnostics have proceeded slowly. Jussi Heiniö, who is in charge of administration and legal affairs, sees the matter also as a lack of marketing efforts.

\section{DECISION-MAKING}

Erkki Vesanen, the Product Development Manager who has worked for Osmo for about thirty years, sees decision-making in Biohit as based on a clear sense of vision and mission, but also as involving a lot of freedom to make decisions on an ad hoc basis, bearing in mind that many issues cannot be predicted beforehand: 
"We have certain broad lines that we follow, an unspoken perspective, and that takes us forward, but we more or less act short-term. I would describe our decision-making system as being the kind where we mainly sit down when we have a problem. Once you are your own boss, there is no sense in having strict frameworks. We do what feels right at a certain moment. If you decide on a strict budget for November of next year during the current October, you are just putting useless pressure on yourself. Of course we have budgets, but we make our decisions for situations as we face them."

Decisions are mainly made in corridors and coffee rooms. In addition, Biohit does of course have an official management group and board meetings, with the administration mainly getting to decide what they are allowed to decide about. Overall, as Osmo sees it, he gives a lot of freedom to his employees, and has done his managing by "walking around":

"My way of doing things is that I let the flowers bloom as long as they stay alive and bloom. My laziness can be seen in the fact that I trust people and let them do things. Most of the time it works. But of course I need to interfere sometimes. Management by walking has been my philosophy, although the current email system has ruined it a bit. In Labsystems, people knew that I was coming, since I was smoking cigarettes and walking around. But I don't smoke anymore and because of the emails that make me stay in my room, my 'management by walking around' has diminished as well. That's a pity."

Vesanen, too, is of the opinion that in Biohit, people have much more freedom that in many other kinds of firm. The procedures are simple, and some typical phases in other firms, such as planning, documentation, and taking on projects are conspicuous by their absence. Vesanen sees this as a very good strategy if there are good people in the firm, but a risky strategy otherwise. Sometimes people disagree, and then it is Osmo who makes the final decision and shows the future direction. However, overall, the strategies of Biohit are strongly based on the firm's clear sense of vision and mission. One strategic move has been the establishment of a production unit in China. The products with the need for the greatest know-how are still manufactured in Finland, but the simpler products are produced in China, where the employees are very hardworking, and get paid one fifteenth of the salary of a Finnish employee.

In Vesanen's opinion, the entrepreneurialism of Osmo - with his strong belief in his own solutions and his willingness to swim against the tide - may have increased with time:

"When you are 30 or 35, you may be more cautious because of the huge risks and debts. As things begin to go well, you may take bigger risks, because, when you are 66, you don't think so much about what you'll do at the age of 90 - you look more at the potential of something over the next two years. But maybe this is just speculation."

\section{THE FUTURE}


At the present time (March 2010), Osmo is 66 years old, but as Vesanen points out, he is "still going strong." However, Biohit is in the throes of various changes, since Osmo does not want the company to be based solely on himself; his intention is to take a less central role in the near future. Osmo also has plans to divide Biohit into two units: Liquid Handling and Diagnostics. The reasons for this are connected to the differences between the two product lines. Up to now, the liquid handling business has financed the diagnostics business, but there are strong expectations that the diagnostics business may soon become a business of its own. Osmo has hired people who will most probably run these companies; these people are now learning the business and planning the future, together with Osmo and the management of Biohit. However, Osmo believes that he cannot really train future managers. They need to take their places and hold the reins, learning about essential issues themselves. Osmo himself plans to remain a fulltime board member in the future and to continue with his dearest hobby, innovation. Regarding the next generation, Osmo has given his three children the freedom to think independently, but none of them are ready to run Biohit, at least at this point:

"Maybe I' $m$ a bit sorry that I never forced the boys to come with me into the business. I should have done that if I had wanted one of them to carry on with the business at this point. But I didn't want to act that way. They have had the freedom to choose, just like my employees. I am not sure about the two youngest boys, what they will do in the future. Both of them work for Biohit part-time as well as studying. But my eldest son became a chiropractor after he graduated in chemistry. There were no interesting tasks for him in Biohit and he changed to chiropractic. He doesn't want to work for Biohit. Of course all my sons own shares in the company. But it doesn't guarantee their happiness, money is spent so quickly. At best, they can create something themselves as well."

The oldest son, Vesa, was involved in running the subsidiary of Biohit in the USA, but left the company quite soon to concentrate on chiropractic. Joel has been involved in running the daily routines of Biohit for some time. Ville has a part-time job in Biohit on the technical side of product development, aside from his studies.

With regard to the next five years, in addition to establishing the two independent companies, there is a plan to start to share profits among shareholders in order to encourage them to remain shareholders in the future. Up to now, shareholders have not received any dividends, since all profits have been utilized for research and development, sales, and marketing. The liquid handling products are the basis of current income, and along with diagnostics, there are high expectations for the coming years. Within the next five to eight years, liquid handling should double the current revenue, and as far as diagnostics is concerned, a breakthrough is expected: this sector should become a firm with revenues of 100 million Euros. The current management would regard it as a real failure if these visions were not fulfilled.

Vesanen believes that the biggest threat in the future will be related to the ownership base: 
"I don't see it as any kind of problem if Osmo is no longer an executive. The real problem is related to the ownership base. It really makes a big difference whether or not this is a familyowned company, whether it is owned by financiers, or whether it is a subsidiary owned by a big corporation. I am sure that if our strong innovation orientation came to an end, if people with long-term views were fired, and if expenses were cut to a significant extent, it would be a real threat for most of us. Of course, someone could make a lot of money out of Biohit for several years, but in the end, it would mean something totally different for us."

Osmo believes that the biggest threat in the future is time:

"Time goes so fast and the implementation of the objectives we set gets delayed. Doctors accept innovations slowly. But we'll wait and see. Our expectations are high, anyway. And anyway I have a great belief in my innovations. And in creating something new at the same time as well. I really like the idea of being able to concentrate more on product development in the coming years."

Oili, who has worked in the enterprises throughout her adult life, and who has never had a holiday or been away from work because of illness, summed up their entrepreneurial history in the following terms:

"Entrepreneurship has been great fun and a natural part of our lives. It has been so interesting! It was especially interesting when we launched Biohit, and people were asking how we were doing, and we answered, 'If you think about the situation in five years, we are doing just fine, but now we just need to survive the next five days.' Of course Osmo has been away from home a lot, since he has been very involved with his business - the more so the older he has got - but what else should we have done? I must say that I sort of feel that I have had the chance to live many lives during the different stages of our business life. Such an interesting life!"

Osmo says that he is getting to be an old man, but at the same time he thinks that his business is just getting off the ground:

"This is only the beginning. If I think about the owner and founder of Ikea [a Swedish company selling furniture and household items], he was launching companies at the age of 80. And his companies are doing extremely well around the world and he's in good shape both mentally and physically. So why not me as well?"

\section{Financial performance}

Financially Biohit has performed well over the years (see Exhibit 5). Net sales have increased annually since the founding of the company, signaling a growth in business ventures. In recent years the growth in sales has continued, but there have been years in which profits have been low or when there have been losses. The reasons for the poorer years might be major expenditure in R \& D or the marketing of new products. Growth 
can be seen in terms of the number of employees in the company. Exhibit 5 shows that for the past five years, staff numbers have increased in Biohit. In terms of the share price, the performance of the company has not been outstanding. When Biohit went public in 1999 the share price was €5.20. The share price reached its peak in the early months of 2000 when shares were quoted at $€ 12.20$. Since then, the share price has gradually declined, maintaining a price between $€ 2$ and $€ 3$, with an occasional rise above the $€ 3$ mark. In January 2010 the share price went up to $€ 4.41$, but it fell back quickly afterwards.

Exhibit 5. Financial performance of Biohit, 2005-2009.

\begin{tabular}{|c|c|c|c|c|c|}
\hline $\begin{array}{l}\text { Unless otherwise stated, figures } \\
\text { are presented in millions of euros }\end{array}$ & 2005 & 2006 & 2007 & 2008 & 2009 \\
\hline Net sales & 28.66 & 31.41 & 33.01 & 35.10 & 35.37 \\
\hline Change in net sales, \% & $7.3 \%$ & $9.6 \%$ & $5.1 \%$ & $6.3 \%$ & $0.8 \%$ \\
\hline Operating profit/loss & -33 & -143 & -197 & 1.31 & 1.19 \\
\hline$\%$ of net sales & $-0.1 \%$ & $-0.5 \%$ & $-0.6 \%$ & $3.7 \%$ & $3.4 \%$ \\
\hline $\begin{array}{l}\text { Profit/loss before extraordinary } \\
\text { items and taxes }\end{array}$ & -256 & -607 & -1.12 & 996 & 669 \\
\hline$\%$ of net sales & $-0.9 \%$ & $-1.9 \%$ & $-3.4 \%$ & $2.8 \%$ & $1.9 \%$ \\
\hline Profit/loss before taxes & -256 & -607 & -1.12 & 996 & 669 \\
\hline \% of net sales & $-0.9 \%$ & $-1.9 \%$ & $-3.4 \%$ & $2.8 \%$ & $1.9 \%$ \\
\hline Return on equity, \% & $-1.6 \%$ & $-6.1 \%$ & $-11.9 \%$ & $7.4 \%$ & $3.1 \%$ \\
\hline Return on investment (ROI), \% & $0.5 \%$ & $0.0 \%$ & $-0.6 \%$ & $8.2 \%$ & $5.8 \%$ \\
\hline Equity ratio, \% & $51.5 \%$ & $49.4 \%$ & $43.6 \%$ & $46.5 \%$ & $46.8 \%$ \\
\hline Investments in fixed assets & 1.99 & 1.93 & 2.08 & 1.21 & 2.40 \\
\hline \% of net sales & $6.9 \%$ & $6.1 \%$ & $6.3 \%$ & $3.5 \%$ & $6.9 \%$ \\
\hline R \& D expenditure & 1.63 & 1.69 & 2.01 & 2.04 & 2.41 \\
\hline$\%$ of net sales & $5.7 \%$ & $5.4 \%$ & $6.1 \%$ & $5.8 \%$ & $6.8 \%$ \\
\hline Total assets & 27.85 & 27.32 & 27.34 & 27.11 & 27.40 \\
\hline Personnel, average & 295 & 310 & 352 & 369 & 370 \\
\hline
\end{tabular}

Profitability figures such as return on equity (ROE) and return on investment (ROI) can be found in Biohit's financial statements. The financial statement for 2009 provides figures from 2005 until 2009. The return on equity has not been particularly strong during those years, but it has seen an increase in 2008 and 2009. From 2005 through 2009, ROE was $-1.6 \%,-6.1 \%,-11.9 \%, 7.4 \%$, and $3.1 \%$. Return on investment follows the same modest pattern. From 2005 through 2009, ROI was $0.5 \%, 0.0 \%,-0.6 \%$, $8.2 \%$, and $5.8 \%$. 
${ }^{i}$ Finnish pronunciation corresponds closely to how the words are written, with all letters pronounced. In everyday English orthography the pronunciation of Suovaniemi can be represented as SOO-oh-va-NEE-em-i (with stress on the capitalized elements).

${ }^{\text {ii }}$ In this case study he is referred to by his first name, Osmo, to distinguish him from his wife, Oili Suovaniemi, who also has an important role in the company.

iii One Euro was worth 5.95 finmarks when Finland joined the Euro in 1999.

iv The inventions were the single- and multichannel, adjustable, mechanical pipettes (Finnpipettes) and vertical light path photometry, together with its instrument applications, e.g. FP-, Multiskan-, Fluoroskan, Luminoreader,

Bioscreen-, Auto-EIA analyzers and various immunoassays. These inventions have been utilized so extensively that they can reasonably be called global industrial standards.

\section{References}

Biohit, 2002. Aggressive Innovation and Patenting Strategy - the Way to Success and National Well-Being. http://www.biohit.com/resource/files/media/articles/biohit-innovation-patentingstrategy.pdf 


\section{Exhibit 6. Company and subsidiary management in March 2010.}

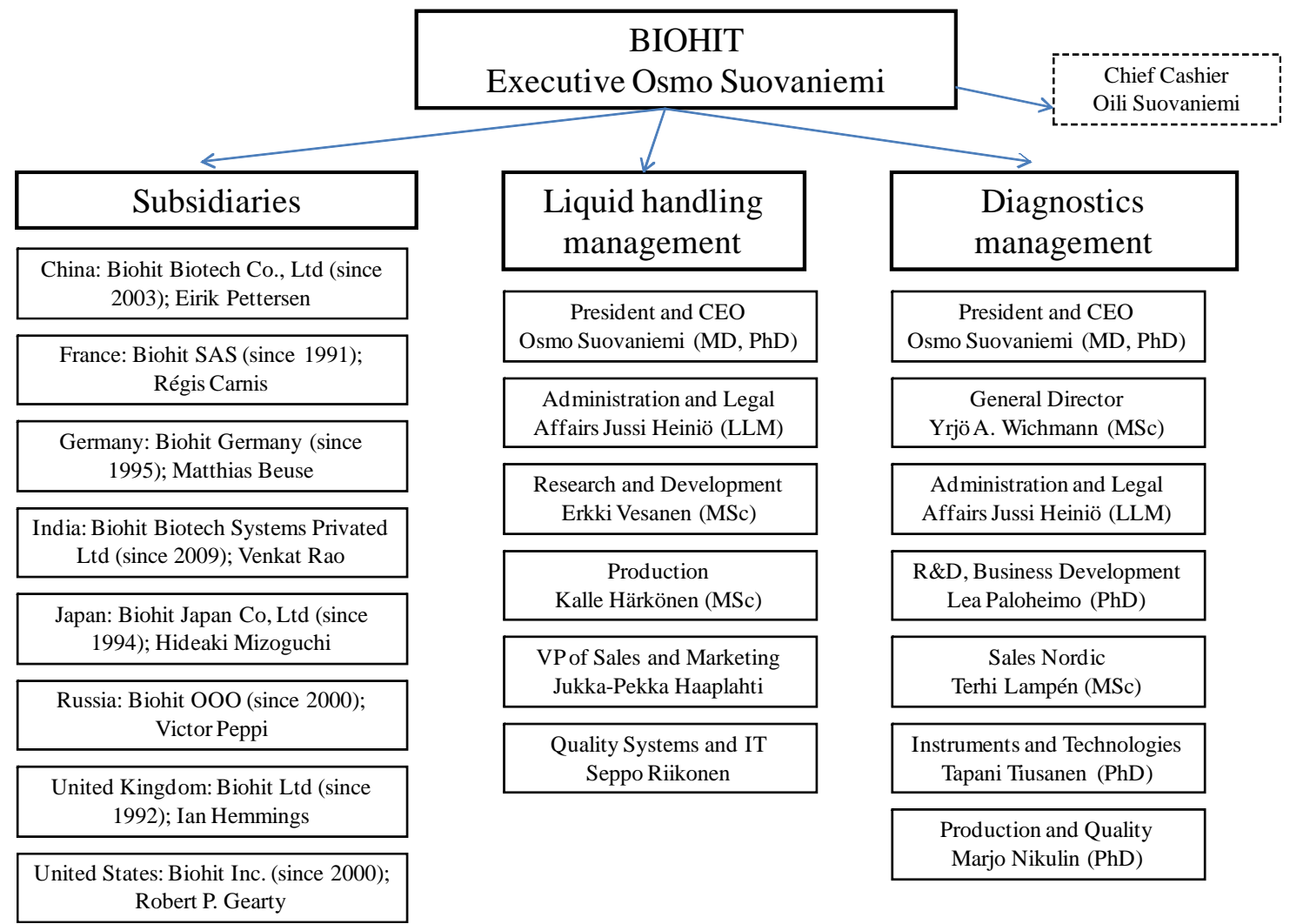

Board of Directors

Chairman

Mr Reijo Luostarinen, DSc (Econ.), Professor

Members

Mr Jukka Anti-Wuorinen, BSc (Econ)

Mr Kalle Kettunen, MSc (Eng), MBA

Mr Eero Lehti, MSc (SocSc)

Mr Mikko Salaspuro, MD, PhD, Professor

Mr Osmo Suovaniemi, MD, PhD, Professor

Ms Ainomaija Haarla, DSc (Tech), MBA 


\section{Exhibit 7. History of Biohit (source: www.biohit.com).}

\begin{tabular}{|c|c|c|}
\hline Year & Events & $\begin{array}{l}\text { Net sales } \\
\text { EUR million }\end{array}$ \\
\hline 1988 & $\begin{array}{l}\text { Establishment of Biohit Ltd. } \\
\text { Electronic pipette development begins } \\
\text { Establishment of Locus genex Ltd., the current diagnostics division of the } \\
\text { Biohit Group }\end{array}$ & 0.49 \\
\hline 1989 & $\begin{array}{l}\text { TEKES[1] funding received for the electronic and mechanical pipettes, } \\
\text { pipette tips, and microplates }\end{array}$ & 0.12 \\
\hline 1990 & $\begin{array}{l}\text { Worldwide introduction of the first ergonomically designed electronic } \\
\text { pipette, the Proline } \\
\text { Assembling of pipettes and injection molding begins in Kajaani, Finland } \\
\text { Introduction of first monoclonal antibodies }\end{array}$ & 0.49 \\
\hline 1991 & $\begin{array}{l}\text { TEKES funding for the development of mechanical pipettes } \\
\text { Establishment of the first Biohit subsidiary, in France } \\
\text { Introduction of new monoclonal antibodies }\end{array}$ & 2.1 \\
\hline 1992 & $\begin{array}{l}\text { Launch of the Proline mechanical pipette } \\
\text { Launch of the multichannel Proline electronic pipette } \\
\text { Establishment of subsidiaries in Italy and the UK } \\
\text { PhD Thesis of Tapani Tiusanen: An application invention of vertical } \\
\text { measurement; the self-correcting, multiparameter measuring instrument }\end{array}$ & 4.2 \\
\hline 1993 & $\begin{array}{l}\text { Launch of the multichannel Proline mechanical pipette } \\
\text { Co-operation regarding liquid handling products begins with Eppendorf } \\
\text { and bioMérieux }\end{array}$ & 6.4 \\
\hline 1994 & $\begin{array}{l}\text { Development of the renewed electronic pipette } \\
\text { Co-operation with Ortho Diagnostic Systems of Johnson \& Johnson begins } \\
\text { Establishment of joint venture in Japan } \\
\text { PhD Thesis of Osmo Suovaniemi: The vertical measurement invention, its } \\
\text { applications and the invention of electronic liquid handling devices }\end{array}$ & 8.4 \\
\hline 1995 & $\begin{array}{l}\text { Launch of several new liquid handling products } \\
\text { Establishment of a Biohit subsidiary in Germany } \\
\text { Co-operation with Eastman Kodak Co. Clinical Diagnostic Systems (later } \\
\text { acquired by Johnson \& Johnson) begins }\end{array}$ & 10.5 \\
\hline 1996 & $\begin{array}{l}\text { Reinforcement of international sales and marketing } \\
\text { The GastroPanel program begins } \\
\text { PhD Thesis of Sari Ylätupa: An application invention of vertical } \\
\text { measurement and immunoassays; the determination of cFn from blood } \\
\text { samples and its importance in cancer diagnostics }\end{array}$ & 12.6 \\
\hline 1997 & $\begin{array}{l}\text { Move into new facilities in Helsinki } \\
\text { ISO } 9001 \text { quality system certification } \\
\text { Co-operation with Becton Dickinson and 3M begins } \\
\text { Given EUREKA[2] status, on the basis of which TEKES funding is } \\
\text { received for the GastroPanel program }\end{array}$ & 14.4 \\
\hline 1998 & $\begin{array}{l}\text { Pipettes assembly and injection molding begins in Helsinki } \\
\text { Locus genex Ltd. and Biohit Systems, Inc. become Biohit Group } \\
\text { companies } \\
\text { External evaluation of the first test kit (Pepsinogen I) of the GastroPanel } \\
\text { program } \\
\text { PhD Thesis of Auli Linnala: Basic research on Biohit's monoclonal } \\
\text { antibodies (cFn and tenascin), which are related to cancer diagnostics }\end{array}$ & 16.8 \\
\hline 1999 & $\begin{array}{l}\text { Listing on Helsinki Exchanges (New Market list) } \\
\text { Continuation of aggressive patenting policy }\end{array}$ & 20.5 \\
\hline
\end{tabular}




\begin{tabular}{|c|c|c|}
\hline 2000 & $\begin{array}{l}\text { Completion of new production premises in Kajaani } \\
\text { Accreditation of Biohit's pipette calibration laboratory in Finland } \\
\text { Preparation to commence global marketing and sales of diagnostic tests and } \\
\text { analyzing systems } \\
\text { Commencement of sales of instruments } \\
\text { Reinforcement of international collaboration and customer service } \\
\text { organization through acquisitions in the US and Russia }\end{array}$ & 24.2 \\
\hline 2001 & $\begin{array}{l}\text { Marketing of the GastroPanel begun for research use; several clinical } \\
\text { evaluations under way } \\
\text { Development of test kit for cellular fibronectin (cFn) } \\
\text { Completion of new production premises for diagnostics in Helsinki, } \\
\text { Finland } \\
\text { Service laboratory operations start }\end{array}$ & 25.5 \\
\hline 2002 & $\begin{array}{l}\text { Launch of the new mLINE mechanical pipette range } \\
\text { Enlargement of the electronic eLINE pipette product range } \\
\text { Continuation of automization at the production premises in Kajaani } \\
\text { Biohit opens a subsidiary in Russia }\end{array}$ & 25.3 \\
\hline 2003 & $\begin{array}{l}\text { Launch of multichannel electronic eLINE pipettes } \\
\text { Establishment of Biohit's representative office in China } \\
\text { Further development of production at the Kajaani plant } \\
\text { Diagnostics business receives ISO } 13485 \text { certification and CE/IVD } \\
\text { compliance }\end{array}$ & 26.2 \\
\hline 2004 & $\begin{array}{l}\text { Launch of multichannel mechanical mLINE pipettes } \\
\text { Launch of quick tests for diagnosis of Helicobacter pylori infection and } \\
\text { lactose intolerance } \\
\text { US Food and Drug Administration (FDA) approval for the GastroPanel test } \\
\text { kit's serum-based } H \text {. pylori test } \\
\text { Prize awarded to Biohit by VWR USA, one of the largest global } \\
\text { distributors of liquid handling products }\end{array}$ & 26.7 \\
\hline 2005 & $\begin{array}{l}\text { China's State Food and Drug Administration (SFDA) grants Biohit } \\
\text { marketing authorization for the Pepsinogen I \& II and Gastrin-17 tests } \\
\text { included in the GastroPanel examination } \\
\text { New contracts help to strengthen the company's OEM business }\end{array}$ & 28.7 \\
\hline 2006 & $\begin{array}{l}\text { Liquid Handling business receives ISO } 13485 \text { certification (CE/IVD } \\
\text { compliance) } \\
\text { Biohit opens subsidiary and starts pipette assembly in China } \\
\text { Launch of the electronic eLINE Dispenser for multiple dispensing } \\
\text { Chinese scientists recommend GastroPanel for use in Chinese health care } \\
\text { Biohit announces new products that reduce carcinogenic acetaldehyde in } \\
\text { the mouth and stomach } \\
\text { Launch of the Helicobacter pylori IgA/IgG ELISA test }\end{array}$ & 31.4 \\
\hline 2007 & $\begin{array}{l}\text { Launch of the new Proline Plus mechanical pipette range } \\
\text { Launch of GastroView (3-in-1 Indigestion Test) in the UK } \\
\text { Agreement with VWR concerning liquid handling product sales in Europe }\end{array}$ & 33 \\
\hline 2008 & $\begin{array}{l}\text { 20th Anniversary of Biohit } \\
\text { Launch of ColonView faecal occult blood test } \\
\text { Launch of new filter tips } \\
\text { Accreditation of Biohit's calibration laboratory in Germany }\end{array}$ & 35.1 \\
\hline 2009 & $\begin{array}{l}\text { Establishment of Biohit subsidiary in India } \\
\text { Launch of Pipetting Academy } \\
\text { Launch of SafetySpace }{ }^{\mathrm{TM}} \text { Filter Tips } \\
\text { Renewal of product packages } \\
\text { Accreditation of Biohit's pipette calibration laboratory in Russia }\end{array}$ & 35.4 \\
\hline 2010 & $\begin{array}{l}\text { Launch of the Acetium capsule to reduce carcinogenic acetaldehyde in } \\
\text { anacidic stomach } \\
\text { Establishment of a representative office in Singapore }\end{array}$ & \\
\hline
\end{tabular}


[1] TEKES = The National Technology Agency of Finland.

[2] EUREKA = Europe-Wide Network for Industrial R \& D. A framework through which industry and research institutes from 26 European countries and the European Union develop and exploit technologies crucial to global competitiveness and a better quality of life. 